\title{
BEFRIENDING THE BROKEN BODY Understanding the Post-Pandemic Body
}

Soroj Mullick has a Licentiate in Faith Education and a Doctorate in Christian Education from the Salesian Pontifical University, Rome. He is a former faculty of Salesian College Sonada, and has written number of research papers and articles. His area of academic interest includes religion, Theology, and youth Psychology. Currently he serves as co-pastor at Bandel Basilica.

\section{Abstract}

The paper approaches the impact the pandemic has had on innumerable human bodies, with a philosophico-theological reflection, building on the biblical insights into the human body and the changes it has undergone within Christian tradition. The paper asserts that the notion of perfection on which the Christian ideals of sanctity was created over the centuries have had its negative impact in delimiting the sin dimension of being human, to the body, and in the body, to the sexual. The contemporary issues of gendered body, sexual orientation and identity, seeking expressions across the globe within the western modernity and its aftermath in the rest of the world, through the colonial expansionism needs a critique and the pandemic does a cleansing not only of the physical world but also of the inner psychic world of the post-pandemic human is what the paper delineate.

Keywords: Sexuality, gendered body, sin, pandemic, spirituality.

\section{Introduction}

What does it mean to be human being with bodies - as living and thinking bodies? What is new in the awareness of the body, in the current pandemic times? What relation does it have with the life in the Spirit? How to free oneself from the cult of the body? These questions leave us perplexed. The body has been, for centuries, the subject of suspect and ambiguity. In this background, certain reflections are pertinent during this viral time. 


\section{6 / Soroj Mullick}

Salesian Journal of Humanities and Social Sciences, Vol. XI, No.2 (Dec 2020)

ISSN: 0976-1861 | DOI: 10.51818/SJHSS.11.2020.55-76 | Page: 55-76,

Section: Articles

There has always been a 'Christian' desire to overcome the body which is an expression of vulnerability and the limitations of our will. It is not just a recent tendency-as a result of the modern technologies - but has been in existence long before the present epoch of technological transcendence. The wish to overcome the conditions of the body is also a wish for total freedom, which is a utopia. Are we thinking of replacing the body with other hardware (Sophia with Artificial Intelligence) ${ }^{1}$ for this total freedom? In a highly technological society, the body will increasingly become a burdensome attachment.

However, one thing has become clearer. The body hassimultaneously-become an important theme of reflection and spirituality. The body (theology of the body) and practices relating to the body constitutes major themes of current discussions - but are often destructive. We need, therefore, an accurate perception of what is happening to the body, to have a clear understanding of the contemporary, global reality; and to make a critical study of the biblical elements - of a way of thinking bound up with the body and with the idea of incarnation-not to negate the body, but to love it. Because of the utopia of the perfect body inherent in all our modern cures, it is necessary to grapple with the image and myths existing around the understanding of the body. A good life need not necessarily be identified with the immortality of one's own gene. The corporality - the body has values of its own as it is by no means just a physiological entity - but has been constituted culturally.

Starting with the evolutionary narrative of the body, this paper attempts to address its diverse dimensions, and implications. It proposes spiritual reading in the context of the contemporary global reality and also the idea of an incarnational cosmic body. The Christian understanding of sin has shamed the body in various ways. This suffering, colonized, conditioned, mixed, yet

1 Sophia, a social humanoid robot developed by Hong Kong-based company Hanson Robotics, was first turned on $14^{\text {th }}$ February 2016. Her first public appearance was at South by Southwest Festival (SXSW) in mid-March 2016 in Austin, Texas, United States. 
a resilient body, continues to challenge theology of the body and its spirituality. An integrated and renewed body and mind, with a cosmic-consciousness in the midst of the pandemic, is a sure way towards a fulfilled and healthy living.

\section{I}

\section{Social Implications of the Globalized Body}

\section{Being the Natural Body}

The body is probably the only psychophysical entity in the world, which can be guided directly by consciousness and through that, we have a direct access to the world. The body is constantly present, and is expressed in moods and dispositions which accompany the content of our consciousness. Our bodily capacities, the sensuality, are the condition of all knowledge. The provocation of the senses stimulates, gives pleasure and leads to the satisfaction of sensual tendencies. This pressure is exercised in unconscious reflexes or drives. It is an expression of one's individuality, occupying a concrete place in space and time through which we achieve an orientation and position. There are advantages in seeing, hearing, touching and tasting which are articulated through different bodily modes. The body itself is the first expression of culture and the very language has a bodily disposition.

The body functions as a boundary. It is directly bound up with human psyche and habits and at the same time is the medium which associates one with what the self is not. It is the vehicle of being in the world and through it one identifies himself/herself with certain futuristic plans. The body is the first medium which relates to the world. Interpersonal relationship takes place in an area of vision, of hearing, of sensing and of touching. There is a direct involvement of persons by bodily contact and interaction. However, through writing, social media and other means of verbal and external means of communication, there is a tendency to make body superficial. The body becomes an object to be shaped, something that which is attached to a person but is no longer a psychophysical entity. 


\section{8 / Soroj Mullick}

Salesian Journal of Humanities and Social Sciences, Vol. XI, No.2 (Dec 2020)

ISSN: 0976-1861 | DOI: 10.51818/SJHSS.11.2020.55-76 | Page: 55-76,

Section: Articles

Speaking about the renaissance of the body, Regina Ammicht Quinn of University of Tubingen, argues that the "body, which today has come back into the centre of interest, does not speak what is expected of it and hoped from it: the language of truth, authenticity and naturalness." 2 The body is no longer a place which can be 'occupied' by religion clearly and without loss-any more than the cosmos and society are. This is certainly not for Christianity, because hers is a history of guilt. Today, 'both pillars of theology, God and human beings' seem to be shaky foundations. What is our role, therefore, to make sure that man and woman live truly with his/her body in its fullness?

Is there not a risk of dismembering the body, with the consequent loss of the universal sense of the body? Is it not dangerous to have obsessive attention to one's own body at the cost of breaching relationship with others? The body is the subject, not only of touch and vision, but of all our actions and passions. When it is being created (born), it distinguishes itself from the mother and becomes the object of care, of love; it comes in interaction with other bodies and ultimately realizes itself.

Can I say I am my Body? Or I have my body? Can I reflect on myself, taking this body as an object? My body lives the adventure of being born, of growing and weakening, of eating, of coming in contact with others, of loving and of dying. My story, my desires, joys and sorrows, hopes and waiting, delusions, victories and failures are all inscribed in my body.

The body as "flesh", is negatively perceived in its own limitations making it the place of defence and aggression. Nevertheless, today we are more conscious that we have our body forgetting that it also has a spirit. It is then that the body speaks and confers dignity to the physical presence. It does not speak only with words but also through its very being. How to live this body? What about the words not spoken by the body but which is innate in itself? If we

${ }^{2}$ Regina Ammicht-Quinn and Elsa Tamez (eds), The body and religion, (SCM Press, 2002), 7. 
BEFRIENDING THE BROKEN BODYUnderstanding the Post-Pandemic Body / 59

Salesian Journal of Humanities and Social Sciences, Vol. XI, No.2 (Dec 2020) ISSN: 0976-1861 | DOI: 10.51818/SJHSS.11.2020.55-76 | Page: 55-76,

Section: Articles

don't understand what it does not speak, we will destroy the body making it an absolute idol, a total emptiness to which to sacrifice one's life. The human being, in fact, becomes the interpretation that one gives to one's body.

\section{An Isolated and Self-Cultivated Globalized Body}

The Body is understood in the Cartesian philosophy as a machine, the functioning of which is ultimately to be derived from mechanical interactions. It was only on the basis of this notion of the body that modern scientific disciplines could emerge, including modern medicine. What happens to/in this body is recognized through access from outside. We not only think of the body in this term but many of us live it too. This has found its way deep into forms of life and cultural practices, in ways of dealing with sickness and health, in attitudes to physical work, in spheres like cosmetics and sport and even in the legal regulations. This view is a globalized one, and not just European or Western. The idea of the body got materialized in various corners of the world through dissemination of the Western science, medicine, industry and technology - through the modern means of communication.

A globalized body is isolated from connections with its environment and from social and biographical contexts and thus allows causes and effects to be directed. Thus we have an approach to the body under the eye of the physician (in the present contextCovid hospitals, isolation, under ventilators are reminiscent of that gaze) or the natural scientist. Body is understood as an instrument and is treated accordingly. This attitude has led to a very widespread direction of bodily functions in everyday life: fitness training, treating one's own body for high achievement, the compulsion for discipline-and the appearance of the body became an essential part of the self in representing it through cosmetics, dresses, and jewellery. A combination of fashion with fitness techniques has established the objectivistic concept of the body in the sphere of beauty. In all of these remains the tendency to treat the body merely as an instrument. 


\section{0 / Soroj Mullick}

Salesian Journal of Humanities and Social Sciences, Vol. XI, No.2 (Dec 2020)

ISSN: 0976-1861 | DOI: 10.51818/SJHSS.11.2020.55-76 | Page: 55-76,

Section: Articles

In contrast, with the understanding of body as a subjective given, as the nature that we ourselves are, there came about sexual reforms, reforms in food and clothing and naturist culture. The idea of being natural became the leading idea around 1900s. Today, in an age of globalisation bodies are no longer limited historically or culturally. The practice of self-cultivation, the Yoga, the martial arts, different forms of alternative medicines (and herbal immunity boosters!) will also represent a counterbalance to the globalisation of Western concept of the body in other parts of the world. In dominant Western traditions the very concept of body has been formed in opposition to mind. It is defined as the place of biological data, of the material, of the immanent. It has been conceptualised as that which marks the boundaries between the interior self and the external world.

It is appropriate to stress that women's bodies are not only recognized and venerated for their reproductive capacity, but that they are also subjects of desire. The body, abode of delights and pleasures, the dual body of women and men, is the principle of being on earth, in fusion with the immediate surrounding and with the origin of the cosmos. This idea can be caught in the remnants of epic poetry, songs, narratives and metaphors in various cultures and languages. Even these vestiges can begin to reveal incarnate universes that escape the Western master narrative of spirit over flesh.

\section{Body: Commodity and Pleasure}

What is attractive in the short term may run counter to what is best in the long run and persons may go astray ignoring warnings. Human beings considered either as individuals or as collective bodies, do not follow their best interest always. This is relevant for understanding the body in one's personal life and interpreting larger body movements through the human evolution. When an activity is necessary for sustaining life and guaranteeing its continuation, it is one of nature's methods to make it pleasurable. It is instructive to note how people respond, positively or negatively, to body's natural signals. Think of the attraction of one body 
towards another, opposite to it. The normal human being responds to this attraction positively. This pleasure finding act is accepted as something worth cultivating for its own sake even beyond what is necessary for sustaining healthy body and vitality. However, the signs are clear that this search for pleasure has overstepped the limits in utter defiance of nature's signals. How people die of diseases from overeating (Wuhan wet market as the starting point of Corona spread) ${ }^{3}$, from over pleasure seeking and merrymaking. Our commercial civilization has produced the idea of the "economic man" to do duty for the whole man, considered it rational to accept pleasure as the basic goal of life and concluded that purchasable commodities are the principal avenues for attaining that goal. When this pleasure seeking is accepted as the basis of life, it has a strong subterranean hold on our psyche.

A pleasure giving body loses its capacity to yield positive pleasure as we come to have more and more of it. The possessiveness of one's body is not particularly productive of happiness or lasting pleasure. Here pleasure stands for something more passing and unsteady, while happiness is steadier and closer to a state of peace and equilibrium. This happiness comes from union of bodies. Pleasure is derived from gratification of the senses. It belongs to a world where the feeling of separateness dominates, while happiness stresses on the 'other' as opportunities for one's self-realization through an expansive sympathy. The very nature of the body has the principle of pleasure. It is, therefore, a question of orientation.

\section{Body: Behaviour and Social Interactions}

The post-pandemic persons' social skills in physically interacting with others, especially those who stays a prolonged period in

${ }^{3}$ Chinese virologist Dr Li-Meng Yan differed from the above theory and has claimed that the novel coronavirus was made in a government controlled laboratory in Wuhan and that Sars-CoV-2, a "high mutant virus" neither originated from Wuhan seafood market, nor from nature. Cf. Hindustan times, 14 September 2020, https://www.hindustantimes.com/world-news/covid-19made-in-wuhan-lab-controlled-by-china-govt-claims-virologist-offers-evidence/ story-JJTyD7Ts61FLOzPvEQHHQL.html, 15.9.2020 


\section{2 / Soroj Mullick}

Salesian Journal of Humanities and Social Sciences, Vol. XI, No.2 (Dec 2020)

ISSN: 0976-1861 | DOI: 10.51818/SJHSS.11.2020.55-76 | Page: 55-76,

Section: Articles

isolation, will suffer from a negative impact. Lack of such interactions leads to negative cognitive, emotional and physiological effects. Separated from society - thanks to the pandemic induced social isolation-can make one impulsive, awkward and intolerant, losing one's facility and agility in social behaviour and movements. ${ }^{4}$ Physical longing to be with others in times of isolation is a normal biological signal that one has to be accustomed to. It's an odd social malaise with biological reasons, though not a pathology or mental disorder. ${ }^{5}$ Even the introverted self can suffer a mortal threat. Physical interaction gives a sense of belonging, as a part of a wider community. According to Stefan Hofmann, a professor of psychology at Boston University, social isolation breaks that security and disables one to respond to the social subtleties in life. As we live with the lethal Corona virus, we become more self-conscious of the risk, and feel uncomfortable with other people, thus we try to avoid, withdraw from the social. We cannot deny our dependence on the normal physical contact and interactions in words, gestures and expressions. Post-pandemic efforts must be to connect with others with confidence even when values and personalities might see some change.

\section{II}

\section{Cosmic Body within the Colonized Global Reality}

\section{Shaming the Gifted Sexual Body}

We experience in life the inner urge to meet the 'other': the body as the word not said, does not complete itself until it meets the 'other' half. It is not just the desire for physical completion but it is concerned with the total bodily human being in relation to the 'other'. In the Bible the body of man and of woman are created in

${ }^{4}$ Cf. Kate Murphy, We're All Socially Awkward Now, The New York Times, Sept. 1,2020

https://www.nytimes.com/2020/09/01/sunday-review/coronavirus-sociallyawkward.html, 13.9.2020; See also, Sunday Times of India, 13 September 2020, p. 10.

${ }^{5}$ Stephanie Cacioppo, the director of the Brain Dynamics Laboratory at the University of Chicago holds on to this theory. 
BEFRIENDING THE BROKEN BODYUnderstanding the Post-Pandemic Body / 63

Salesian Journal of Humanities and Social Sciences, Vol. XI, No.2 (Dec 2020)

ISSN: 0976-1861 | DOI: 10.51818/SJHSS.11.2020.55-76 | Page: 55-76,

Section: Articles

God's image and likeness in as much as they are masculine and feminine (Gen 1:26-27). This strain continues in the "flesh of my flesh and bone of my bone" (Gen 2: 18-23), and 'that they be one body" (Gen 2:24). ${ }^{6}$ The man recognizes and discovers himself in the light of the woman. The diversity of the sexes remain incomplete in itself and each defines itself in relation to the 'other'. There is no place for Narcissism. My Body is called to live in a different way, being the reflection of the glory of God, "the temple of God" (1 Cor 3:16).

The negative judgment on sex surfaced within Christianity in the search for perfection as a human experiment. The Fathers of the Church, considered the human person as a quasi-political entity within which the soul struggled against the body. St. Augustine deals with men's problems and dwells at length with how lust takes control of man, making sexual activity and the sexual organs shameful. He proceeds to pair this problem of sexual desire with that of sexual pleasure. This attribution of sin to sex became a fixation and infiltrated the whole culture. The sexual organs as evil or ugly derives from the traditional Christian association of sex with evil/sin. The link adversely affected healthy sexual relationships in such a way that what is actually experienced as pleasurable and attractive is paradoxically prohibited by religion as evil and ugly. This creates unnecessary tension between will and duty, and affects religion and religious people. People refrain from healthy relationships and engage in promiscuous sex in secret so as to 'steal' a pleasurable moment under cover as the occasion arises. By forbidding 'the fruit' one makes it more attractive. Nietzsche puts it thus: "Christianity gave Eros poison to drink - he didn't die from it, but he did degenerate, into a vice."7

${ }^{6}$ Jean Vanier, the founder of the worldwide l'Arche communities, referring to these bible references, writes on relationship between man and woman, with profound insight into the mystery of human sexuality, cf. Jean Vanier, Man and Woman He made Them, (London: St. Paul Publications, 1985), 49-61.

${ }^{7}$ Friedrich Nietzsche, Beyond Good and Evil, Friedrich Nietzsche Internet Archive, 2003, 168-169. https://www.marxists.org/reference/archive/nietzsche/1886/ beyond-good-evil/ch04.htm, 18.9.2020. 


\section{4 / Soroj Mullick}

Salesian Journal of Humanities and Social Sciences, Vol. XI, No.2 (Dec 2020)

ISSN: 0976-1861 | DOI: 10.51818/SJHSS.11.2020.55-76 | Page: 55-76,

Section: Articles

Our sexuality is always three dimensional, including the body, soul and spirit. The body is affirmed and can join with the spirit in celebrating euphoric union, experiencing the transcendence, bliss or intense union, release and cleansing, wonder and the sense of mystery. One goes through a transforming and healing effects that change ones understanding and behaviour resolving internal conflicts and relational discord, and enables one to live with empowerment and purpose-filled lives with meaning and direction. The after effects of the mystical experience reveals promotion of human functioning of the body in relation to self, others, and God. A personal integration is experienced.

Sexuality, is an energy at the disposition of everyone. It depends on how we use it. The body of man/woman is the connection between the necessity and the reasonable freedom. It is beyond the instinct. It is to live in the body to love. The beauty and the harmony of sexuality is an art to understand and accept.

\section{Relating with prevailing Culture of the Body}

The body, which can be attractive, can also be delicate. Many cultures do not allow enough human touching which is an essential element in health care. In short, the body defines me, my limitations. It is at the centre of my actions and thoughts. It puts me in contact with the "other". The mere fact that it occupies a space, I am limited. I am where my body is either in good health or in sicknesses. The body is ever restless and in constant search for its identity and survival. There is also certain coincidence of the opposite effect. It does everything and yet the body is not everything. It is just one entity. It was not before and will not be after; it knows what is beautiful and good; it also knows what is bad, ugly and harmful.

Man and woman, from the beginning have lived the limitations of the body as the 'place' of death than life, of defence and attack than acceptance, a narcissistic monotony than harmony with the other. It is considered, therefore, as the material condition of human being either "against" or "for" the 'other', around which the life 
of man/woman revolves. I know myself through the 'other' as a reflection on oneself. In the course of physical interaction between man and woman, pleasure consists in doing things either together or alone. All activities involve the body and one can discover an immense pleasure in just doing things and these activities can be promoted for the mere reasons of health.

The original culture of intimacy in which people received and offered pleasure in different bodily contacts such as embraces, strokes, looks, plays or simply being together to celebrate life, drink and eat together need to be enhanced as a variety of legitimate interaction. In interpersonal relationships, pleasure is much wider than excitement and it consists in doing things together within a shared space. Legitimate pleasures can set the body free from ailments. The body, its exterior liberation, liberation of its sensations, is at the centre of an 'imagined' culture. The body becomes a medium of marketization - a commodity, an idol.

We value the human body, celebrate beauty and life. When we come in contact with person rich in goodness, generosity, dedication, one who can pardon even before an apology, we consider a true beauty of goodness in it because it sheds joy, serenity, harmony and peace. More profoundly, we say that the spirit is the life of the body that goes on, goes forward; that which makes the body alive in the now moment; that which makes it what it is unconditionally, without excuses or being inexcusable.

Our body is the medium of relationship, and in today's pandemic language it (body as medium) itself is the message without which one cannot assert oneself in the world. In this connection, the body is essentially sexual and relational, because it is only through sexually identified relationships that human beings come to be, relate and prolong life. We have to face the present pandemic challenge that threatens to hamper and destroy this universal truth: humans are sexual and relational beings, and not just merely rational. A harmonious relationship between erotic pleasure and Christian morality is necessary so that God's creation can serve life. 


\section{6 / Soroj Mullick}

Salesian Journal of Humanities and Social Sciences, Vol. XI, No.2 (Dec 2020)

ISSN: 0976-1861 | DOI: 10.51818/SJHSS.11.2020.55-76 | Page: 55-76,

Section: Articles

The doctrinal teachings and ethics are in favour of human maturity and they are centred and articulated upon 'responsibility'. We need to live effectively with a culture of the body in which the modern world is immersed.

\section{A Suffering, Resisting and Resilient Body}

The Asian Christian theology is 'body language, heart semantics or soul-syntax', that reclaims the body from the lived experiences. This is quite in contrast to the denigration of the body fed by the Church's tacit valorisation of asceticism and the spirit-body duality. It holds on the humanization of God in the body of Christ that suffers and resists. But the economy of 'signs', (eg. Faith and praxis towards the realization of a global community) served on human bodies especially on women bodies, sexuality and roles, has become distasteful. The body is a victim of negotiation within the intersection of gender, race, caste, class, cultures and religions. Bodies that suffer, bodies that resist constitute the life-blood, and fibre of Christian understanding.

One can think of the bodies (wo/men) that are pinioned by structural and systemic violence in various forms of oppressions. The bodies that suffer are those who experiences suffering not so much in theory but in praxis. Women's body as a lesser body forms the foundational premise of many of the misconception and practices - and hence sufferings. To realise the 'full divinity', as created in God's image - the premise on bodies that suffer-calls for the 'primacy of anthropological element over the ecclesiastical', 'critical over the dogmatic', and 'social over the personal'. An exegesis on the violence of bodies runs the risk of pathologizing bodies that suffer, inscribing such bodies (women) as weak, infirmed and violated. They are subjected to inferiorization, subjugation and victimization.

Within the daily cyclic phenomenon of creation, preservation and destruction, bodies that suffer also resist. They generate new ways of seeing which are grounded, specific and critical - to have control 
over and decide freely on matters related to their sexuality, free of coercion, discrimination and violence. It is the bodies that resist seamless categorizations within the plurality of identities in multiethnic, multi-cultural and multi-religious contexts. The voluntary starvation for the eroticisation of thinness as a beauty myth is the present-day malice inflicted on human bodies. We are living in a period of broken body that suffers and resists for survival.

\section{A Colonized, Conditioned and Mixed Body}

At the beginning of the third millennium, as we think of our body, we are thus faced with an unavoidable reality: our corporeality has been relegated so often throughout the course of our life that it is difficult now to bring it out, to look at it, to concentrate on it. We experience our body, we suffer it, and we go though emotional agony felt within the body that holds the mind, without much attention-may be without even love. Our bodies are ignored or interfered with, subjected to pressure, to business and often humiliated. Bodies are not taken into account. There are policies that condition bodies so that the latter suit the former. The body is the external expression of its power. They are channels of life and show themselves, express themselves. But bodies lose its bearing in a commercialised setting.

The human body is not something outside history, but something that is developed, that we build up every day. How are we developing it today, on the margins of globalisation? Our body registers and carries with it the story of its development - the sorrows, humiliations, pleasures and joys. Our Asian bodies have the imprint of hatred and rebellion, fear and suffering - a fearful body, ashamed of itself and that hides itself and conceals. Yet, it is a seeking body that needs to discover itself and proclaim itself in order to achieve its identity and find its place in the society.

The laws, the state, politics, morality, the family, tradition, the Church have colonized the body. The man's body has colonized the woman's body. This has changed fashion, publicity, money, and 


\section{8 / Soroj Mullick}

Salesian Journal of Humanities and Social Sciences, Vol. XI, No.2 (Dec 2020)

ISSN: 0976-1861 | DOI: 10.51818/SJHSS.11.2020.55-76 | Page: 55-76,

Section: Articles

seduction. We, therefore, are in search of ourselves but it is a complex process. We have reduced our bodies to biological, psychological, social processes since these human beings as bodies in relationship become enigmatic and mysterious, something that always remains to be explained. In an era of so-called globalisation, bodies begin to see its reflection and its dreams in other bodies, which are not its 'other half' but an imposed presence.

In the process of inculturation, learning to experience one's body after the manner of borrowed bodies has become fundamental. A body is accepted, connected to the extent that it adjusts to what is required. We measure and calculate bodies. For example, the function of the models in fashions is not aesthetic, they are there to present not a beautiful body, but a body deformed in order to comply with a particular formal generality, that is to say a structure. So, by guaranteeing one way of living, dressing, or discovering and dreaming the body, the existence of a subjected and 'surrogated' body has always been assured.

III

\section{A Renewed Body with Cosmic-Consciousness}

\section{Theology of the Body and its Spirituality}

John Paul II through his Theology of the Body (1979-1984) ${ }^{8}$, clarifies the spousal meaning of the body in the context of the redemptive human suffering. He holds that the human body reveals God and contemplates the sexual complementarity of man and woman. According to Christopher West, the central thesis of Theology of the Body is that "the body, and it alone, is capable of making visible what is invisible: the spiritual and the divine. It was created to transfer into the visible reality of the world, the mystery hidden since time immemorial in God, and thus to be a sign of it." ${ }^{\prime \prime}$ We are made in

${ }^{8}$ The Pontifical Institute for Studies of Marriage in the Family was started by John Paul II in 1982. See, John Paul II, Man and Woman He Created Them: A Theology of the Body, Trans. by Michael Waldstein, (Boston: Pauline Books \& Media, 2006).

${ }^{9}$ Christopher West, Theology of the Body for Beginners, (Ascension Press 2004), 5. 
the image and likeness of God, and God is love (1 Jn. 4:16). So, we reflect God not simply in the spiritual part of who we are but who we are as masculine and feminine because our bodies as male and female reveal our call. George Weigel, John Paul II's biographer, in the context of the teaching of the spousal meaning of the body, called theology of the body as "one of the boldest reconfigurations of Catholic theology in centuries," ${ }^{10}$ and called the body the ballast and the ship of the Church, some weight in its Hull that will keep it steady as it is going through some rough seas.

Each body is so radiantly unique that it makes one, his own self - what it really means to be male and female, with his/her identified gender. ${ }^{11}$ The tendency to reject such identity has turned into a gender dysphoria, wherein persons struggle to identify with their own biological sex.

The body itself 'speaks' through its "masculinity and femininity. It speaks in the mysterious language of the personal gift." ${ }^{12}$ Therefore, the language of the body must always speak the truth. For example, according to John Paul II, the sacramental marriage "is manifested by the language of the body, a singular language of love originating in the heart."13 The body is not merely an "organism of sexual reactions". But it expresses the whole person, by means of the language of the body while "participating in the eternal plan of love."14 In this context, the Christian understanding of the resurrection of the body brings about the fulfilment of the ultimate meaning of the body, where man and woman find the fullness

${ }^{10}$ Cf. George Weigel, Witness to Hope, USA: Harper Perennial, 1999), 336-853.

${ }^{11}$ Facebook now offers its users more than 58 genders that they can pick from and in United Kingdom it is up to 71 genders. To see the list, Dennis Baron, Facebook multiplies genders but offers users the same three tired pronouns, Feb 28, 2014. https:/ / blogs.illinois.edu/view / 25/110232\#: :text=and \% 20they're\%20free \% 20 to,or\% 20them\%20a\%20happy \%20birthday, 20.9.2020.

12 John Paul II, Theology of the Body, (Cheyenne, WY: Resurrection Publications, 2003), 9.

${ }^{13}$ John Paul II, The Theology of the Body: Human Love in the Divine Plan, (Boston: Pauline Books \& Media, 1984), 370.

${ }^{14}$ Ibid.397. 


\section{0 / Soroj Mullick}

Salesian Journal of Humanities and Social Sciences, Vol. XI, No.2 (Dec 2020)

ISSN: 0976-1861 | DOI: 10.51818/SJHSS.11.2020.55-76 | Page: 55-76,

Section: Articles

of personal donation and communion of persons, through the glorification of his entire "being, (body \& soul), in the eternal union with God." ${ }^{15}$ Ultimately, the spiritualization of the body does not mean that the spirit dominates the body, but that it fully permeates the body. Consequently, "the resurrection will consist in the perfect participation of all that is physical in man in what is spiritual in him."16

\section{Self-Embodiment and Physical Experience of the Other}

"What is being carved in human flesh is an image of the society."17 For example, the notion of purity and impurity applied to the human body is extended to the society. This anthropological understanding of the body is useful in order to understand the Roman imperial construction of body..$^{18}$ But, the body cannot be seen as merely the "biological raw material on which culture operates" or a "kind of vehicle for the expression of a reified social rationality."19

Jesus healed the haemorrhaging woman and the daughter of a synagogue leader, Jairus (Mark 5:21-43), giving back their bodily dignity with its acceptance in the society. The philanthropic yet a phantasmic body of Jesus, walking on the sea and saying to the disciples, "Take heart, it is I; do not be afraid" (Mark 6:45-52), is an embodiment of a being manifested through Jesus's body, which is broken and shared with others. It is a consumed body given in to the persistence of the other (a Gentile, Syrophoenician woman wanting her daughter to be healed) out of physical, emotional and spiritual need (Mark 7:24-30). Jesus' was not a passive body. Physically as he

${ }^{15}$ Ibid. 262.

${ }^{16}$ Ibid, 241.

${ }^{17}$ Mary Douglas, Purity and Danger, (London: Routledge, 1966), 116.

${ }^{18}$ Cf. Dale B. Martin, The Corinthian Body, (New Haven: Yale University Press, 1995), 76.

19 Thomas J. Csordas (ed), Embodiment and Experience: The Existential Ground of Culture and Self, (Cambridge: Cambridge University Press, 1994), 8; see also, Michael Jackson, Paths toward a Clearing: Radical Empiricism and Ethnographic Inquiry, (Bloomington: Indiana University Press, 1989), 123. 
BEFRIENDING THE BROKEN BODYUnderstanding the Post-Pandemic Body / $7 \mathbf{1}$

Salesian Journal of Humanities and Social Sciences, Vol. XI, No.2 (Dec 2020) ISSN: 0976-1861 | DOI: 10.51818/SJHSS.11.2020.55-76 | Page: 55-76,

Section: Articles

went around, he noticed a great number of people were neglected, who needed his care and help, and that a random act of good deeds had to be done (e.g. "Ephphatha" Mantra to the deaf and dumb man, Mark 7:31-37).

Certeau states, "It is the body that is responsible for a truth (of which it is unaware)." ${ }^{20}$ According to Amos Yong, "God touches human bodies, restores human psyches, reconciles thepsychosomatic dimensions of human life, and reconciles human beings" ${ }^{21}$ thus, revealing the saving work of the Spirit, which the embodied and somatic-sensory ministry of Jesus demonstrates. People wondered at Jesus' hand, and asked, "What deeds of power are being done by his hands?" (Mark 6:2). Cultural anthropologists speak of three modes of human beings: emotion-fused thought (eye-heart), selfexpressive speech (mouth-ears), and purposeful action (handsfeet). Of these, the last outward human behaviour covers human actions upon the world of persons and things. ${ }^{22}$ Therefore, the abject body in Christian discourse challenges the social perspective, which denigrates some people as contaminated, 'untouchables', 'broken' ${ }^{23}$ and unworthy because of their close association with the body's disgusting aspects. The physical bodily encounter by Jesus, is best characterized as contacts in action, i.e. taking (Mk 1:31; 5:41), raising (Mk 1:31; 9:27) and touching the sick by the hand (Mk 1:41; 7:33), and laying a hand upon the sick (Mk 5:23; 7:32). In fact, Jesus "placed his hands on every one of them and healed them all" (Lk 4:40). His mere physical presence and ordering voice healed many. ${ }^{24}$

${ }^{20}$ Michel de Certeau, The Mystic Fables, trans. Michael B. Smith, (Chicago: University of Chicago Press, 1992), 5-8.

${ }^{21}$ Amos Yong, "Many Tongues, Many Senses: Pentecost, the Body Politic, and the Redemption of Dis/ Ability", Pneuma 31, 2 (2009): 167-88.

${ }^{22}$ Bruce J. Malina, The New Testament World: Insight from Cultural Anthropology, (Louisville, KY : Westminster John Knox Press, 1993), 73-75.

${ }^{23}$ Jean Vanier speaks of the 'broken' body of humanity and the body of Christ, cf. Jean Vanier, The Broken Body, Journey to wholeness, (London: St. Paul Publications), 126-128.

${ }^{24}$ Jesus' physical presence and his rebuke to the fever, healed Peter's mother-inlaw, who immediately got up and served the guests. Cf. Varghese Alengaden, God in Flesh and Blood, Vol. V, (Indore: Universal Solidarity Movement, 2007), 84. 


\section{2 / Soroj Mullick}

Salesian Journal of Humanities and Social Sciences, Vol. XI, No.2 (Dec 2020)

ISSN: 0976-1861 | DOI: 10.51818/SJHSS.11.2020.55-76 | Page: 55-76,

Section: Articles

In addition, Jesus embraces children in his arms (Mk 9:36; 10:16), the human touch needed for their integral development. Besides, others have touched his body to be healed (Mk 3:10; 5:27- 31). In short, the disfigured body, the female fragmented body "marked by the wound, the mutilation, or the scar" - historical traumas of a person or community - are to be part of human concern and care. The body while it is socially constructed, functions as "an active and performing agent." 25

\section{Pandemic Implications of the Psyche on the Body}

Man is made up of body, soul and spirit. The soul is the realm of self-consciousness and is composed of mind, emotions and will. The spirit is the realm of God-consciousness. The spirit of man is designed to be the place where God lives and reigns. Psychosomatic illness describes a bodily ailment that is caused by maladjustment due to mental or emotional problems. Between 70 and 90 percent of all the illnesses are psychosomatic. In the conscious stage, the body expresses what the soul tells it to do. This material body with soul and spirit is the person, in whom the spiritual faculties inhere. Every organism is composed of prime matter and substantial form (vital principle) that makes it exist as a material substance. Man is an organism - a living body, a sense organism and a rational animal with eyes to see, ears to hear, nose to smell, mouth/tongue to munch and taste, hands to feel and touch. It is the body that experiences the sickness, weakness, disease and pain, but they all affect the whole person (body, spirit and soul).

Today, this above understanding calls for a transformation, as Jesus intended by healing the whole person. According to Deepak Chopra, one of the eight ways of living the mystery of Godconsciousness that Jesus visioned for others is: "The human body

${ }^{25}$ Cf. Pamela B. June, Fragmented Female Body and Identity: The Postmodern, Feminist and Multiethnic Writings of Toni Morrison, Theresa Hak Kyung Cha, Phyllis Alesia Perry, Gayl Jones, Emma P érez, Paula Gunn Allen, and Kathy Acker, (New York: Peter Lang, 2010), 7-12. 
BEFRIENDING THE BROKEN BODYUnderstanding the Post-Pandemic Body / 73

Salesian Journal of Humanities and Social Sciences, Vol. XI, No.2 (Dec 2020) ISSN: 0976-1861 | DOI: 10.51818/SJHSS.11.2020.55-76 | Page: 55-76,

Section: Articles

itself would be transformed, no longer beset with illness."26 In the earlier times the body was considered to be outside of human control and its illness was a punishment from God. But as St. Paul says: "When anyone is united to Christ there is a new creature" (2 Cor $5: 17)$. Jesus, thus intended in universal terms, a new creation with a renewed human existence, beyond the boundaries of dogmatic rituals and sacraments.

\section{Integration of Body-Psyche for Healthy Living}

Life is magnified in the body. ${ }^{27}$ Life therefore, has to be regenerated in the body.$^{28}$ The unity of the person is gained through the integration of various aspects of the human presence, with proper control of the body through the psychic and spiritual activities. Physical movements, physical exercises, body-mind integrated Yoga, Celtic meditation in harmony with the nature, and sports, are the means to overcome the dichotomy of spirit and body. Walking and riding in freedom can also be a form of mysticism in addition to physical exercise.

We can help to gain a physical edge to be our best in daily living and learn strategies to improve physical health. Chronic illness or Corona-inflict can bring both tremendous stress and distress in life, affecting both psychological and physical health. One gets sick from being stressed out. Recovering from a life-threatening illness, or learning how to live with a chronic disease, can take a toll on our mind and body. Studies show that the mind and body are strongly linked and they work together. As the mental health declines, the physical health can worsen. When the physical health declines, one feels mentally down. A positive outlook can help keep one healthy and improve the quality of everyday life by building resilience that helps to adapt to stress, and bounce back in life through strong emotional well-being, healthy relationships and an

${ }^{26}$ Deepak Chopra, The Third Jesus: How to find truth and love in today's world, (London: Rider, 2008), 16.

${ }^{27}$ Cf. Witness Lee, The Knowledge of life, (USA: Anaheim, 2003), 21.

${ }^{28} \mathrm{Ibid}, 26$. 


\section{4 / Soroj Mullick}

Salesian Journal of Humanities and Social Sciences, Vol. XI, No.2 (Dec 2020) ISSN: 0976-1861 | DOI: 10.51818/SJHSS.11.2020.55-76 | Page: 55-76,

Section: Articles

optimistic outlook. A positive confidence in self gives strength and ability to confront life's challenges by learning hard-earned skills in coping with life's situation. Psychotherapy or talking to friend/ someone who would listen, have shown to be effective in regaining behavioural health. ${ }^{29}$

\section{Conclusion}

The post-pandemic world needs a holistically healthy human society to live in. Benedict XVI spoke of a "holistic understanding of the health of society" with a duty towards the environment and the human person, in order to shape human coexistence. For him, the ecology of man comes before the ecology of nature. ${ }^{30} \mathrm{We}$ have been commanded to cultivate and protect the earth. We are to "cultivate creation", "tilling it and keeping it" (Gen. 2:15). What we call "nature" in a cosmic sense has its origin in "a plan of love and truth." God makes "his creatures share in his being, in his intelligence, and in his goodness." This bodily existence has "a duty to exercise responsible stewardship over creation, to care for it and to cultivate it." ${ }^{31}$ In order to save humankind from the danger of self-destruction or from earth predators - anthropocene - the care for creation must be one and the same with care for the "inviolability of human life in every one of its phases and every one of its conditions." 32 The degradation of human physical nature is closely linked to the constantly changing cultural models shaping human coexistence: consequently, "when 'human ecology' is respected within society, environmental ecology also benefits." ${ }^{33}$ We all have the duty to

${ }^{29}$ Cf. For a Healthy Mind and Body, American Psychological Association, https:/ / www.apa.org/topics/talk, 12.9.2020.

${ }^{30}$ Cf. Message of His Holiness Pope Benedict XVI for the Celebration of the World Day of Peace, If you want to Cultivate Peace, Protect Creation, 1 January 2010, n. 6. http://www.vatican.va/content/benedict-xvi/en/messages/peace/documents/ hf_ben-xvi_mes_20091208_xliii-world-day-peace.html, 21.9.2020.

${ }^{31}$ Benedict XVI, Caritas in Veritate, 50.

32 Message of His Holiness Pope Benedict XVI, op.cit, n. 12; see also, Caritas in Veritate, 51, 28, 61.

${ }^{33} \mathrm{CV}, 51$. 
respect each physical 'other', considered both individually and in relation to others ${ }^{34}$ and safeguard an authentic "human ecology" reaffirming the "inviolability of human life." 35 We hold to the beauty and harmony of nature with a vision of the "dignity" of all living creatures, and with certain reciprocity between ourselves and the environment ${ }^{36}$ without being influenced by ecocentrism and biocentrism which can lead to a neo-paganistic pantheism, thus falsely seeing the source of salvation in nature alone, understood in purely naturalistic terms. ${ }^{37}$

Life as a gift from God, is filled with the deepest stirrings and desires of the human heart, seeking the ultimate purpose in life. This life as God's mystery is revealed through the body. The physical human body has a specific meaning. We need, therefore, an integrated vision of the human person-body, soul, and spirit. The feelings contained in the depths of body contribute to the development of certain bodily patterns. These are all learnt. We have received our body, as it is the form and pattern of the movements that reflect the pressure of external events. We express not only our response to the trauma of experience but also the system of self-reliance this has produced. Often for example, in this Covid-19 pandemic season, sicknesses and deaths are the product of the ferocity shown by our social system to our bodies. Today, we have to think for ourselves, look after our bodies, take precaution, improve the immunity and change our own lifestyle, so that the society will slowly begin to change.

Our bodies have terrible potentialities. We are starting this era with a new attitude to the human body in general, one of reconciliation, solidarity in facing the same fate, tenderness, and love. This will help us to care for and rescue those bodies wounded, abused by life. We are on the way to develop new culture of body, thus will give birth to a cosmic body. We can reach the meta-human

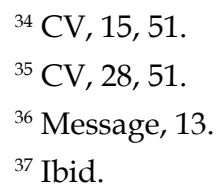




\section{6 / Soroj Mullick}

Salesian Journal of Humanities and Social Sciences, Vol. XI, No.2 (Dec 2020) ISSN: 0976-1861 | DOI: 10.51818/SJHSS.11.2020.55-76 | Page: 55-76,

Section: Articles

body with a supreme-consciousness in life. It will be the pre-eminent body in the new situation, the rescued body of the new ethics, ethics of happiness in corporeality. Justice for this happiness lies in developing structures that would guarantee that we all have the freedom to devise our own life-plan to obtain the means necessary to satisfy our need of every kind, from the most material to needs such as affection, dignity, pleasures etc. The ethics of happiness would be an ethics of bodies, because a happiness that does not take account of the actual, day-by-day bodies of men and women, young and children, is unthinkable. In such a setting the renewed cosmic body-consciousness can bring the dreams into its flesh. 